\title{
KONCEPCJA PRZEBÓSTWIENIA W SYSTEMIE JANA SZKOTA ERIUGENY
}

\begin{abstract}
Streszczenie. W systemie filozoficznym Jana Szkota Eriugeny wszystko, co istnieje, to natura złożona z bytów i niebytów. Poznawalne dla ludzkiego intelektu części natury to byty, natomiast niepoznawalne (w sensie absolutnym) części natury to niebyty. Bytem jest zmysłowa część natury ludzkiej oraz rzeczywistość materialnych form. Dla ludzkiego intelektu Niebytem jest Bóg oraz ustanowione przez Niego prymordialne przyczyny i materia (w swej istocie). Bóg stworzył wszystko z niczego w ludzkiej naturze. Nierozumny wybór człowieka doprowadził do upadku ludzkiej natury i stworzenia, które z doskonałości przeszło do istnienia w świecie doczesnym. Syn Boży - Bóg-Logos stał się człowiekiem, który dokonał odkupienia ludzkości. W ostatecznych czasach rzeczywistość materialna zostanie zniesiona i stworzenie w ludzkiej naturze dostąpi powszechnego powrotu do pierwotnej doskonałości. Ludzkie intelekty dokonają własnego - ostatecznego (samo)sądu i wybrani skierują się ku Stwórcy. Następnie dojdzie do przebóstwienia wybranych - zjednoczenia stworzenia ze Stwórcą bez zmieszania natur, bez zniesienia fundamentalnych różnic ontologicznych oraz bez panteizmu, który w tej koncepcji jest wykluczony. Przebóstwieni będą kontemplować Boga, co oznacza, że będą wiecznie poznawać Niepoznawalnego. Wydaje się, że nawet dla ludzi zgłębiających załomy filozoficznej wiedzy o Bogu w XXI wieku ta szczęśliwa wizja przebóstwienia, które będzie nieustannym procesem poznawania Niepoznawalnego, może być atrakcyjna.
\end{abstract}

Słowa kluczowe: Eriugena, Bóg, Stwórca, stworzenie, natura ludzka, powrót, przebóstwienie

1. Wstęp. 2. Podział natury i stworzenie w prymordialnym człowieku. 3. Upadek stworzenia i obietnica powrotu do Stwórcy. 4. Egzegetyczny kontekst powrotu. 5. Przebóstwienie.

6. Zakończenie. 


\section{WSTĘP}

W systemie filozoficznym Eriugeny wszystko, co istnieje, to złożona z bytów i niebytów natura ${ }^{1}$. Poznawalne dla ludzkiego intelektu części natury to byty, natomiast niepoznawalne (w sensie absolutnym) części to niebyty. Bytem jest zmysłowa część natury ludzkiej oraz rzeczywistość materialnych form, natomiast Niebytem jest Bóg oraz ustanowione przez Niego przyczyny prymordialne i materia (w swej istocie). Bóg stworzył wszystko z niczego w ludzkiej naturze. Nierozumny wybór człowieka (nazywany grzechem pierworodnym) doprowadził do upadku ludzkiej natury i stworzenia, które z doskonałości prymordialnego istnienia przeszło do teofanicznego rozproszenia świata materialnego, określonego czasem i przestrzenią. Bóg-Logos Syn Boży stał się człowiekiem, który dokonał odkupienia ludzkości. W ostatecznych czasach rzeczywistość materialna zostanie zniesiona i stworzenie w ludzkiej naturze dostąpi powszechnego powrotu do rzeczywistości prymordialnej. Ludzkie intelekty dokonają własnego ostatecznego (samo)sądu i wybrani skierują się ku Stwórcy. Następnie dojdzie do przebóstwienia wybranych - zjednoczenia stworzenia ze Stwórcą bez zmieszania natur, zniesienia fundamentalnych różnic ontologicznych oraz bez panteizmu, który w systemie filozoficznym Jana Szkota Eriugeny jest wykluczony. Przebóstwieni będą kontemplować Boga, co oznacza, że będą wiecznie poznawać Niepoznawalnego. Wydaje się, że warto przybliżyć koncepcję przebóstwienia Eriugeny - znaczącego dla naszej cywilizacji autora, potępianego przez papieży i synody², do osoby którego pozytywnie odniósł się na

1 Byty i niebyty, z których w systemie Eriugeny składa się natura, nie stanowią dwóch ontologicznie odrębnych części, lecz są dwoma sposobami ujmowania natury i w tym kontekście bywają nazywane częściami natury.

2 W 848 roku został wywołany spór o predestynację. Udział w dyspucie wzięli (m.in.): król, arcybiskup i Eriugena. Uczestnictwo w sporze odcisnęło piętno na życiu i twórczości filozofa. Stanowisko Eriugeny w kwestii predestynacji zostało dwukrotnie potępione w roku 855 przez synod w Walencji oraz w roku 859 przez synod w Langres. Ostatecznie 
początku XXI wieku papież Benedykt XVI³, zachęcając jednocześnie do zwrócenia uwagi na inspirujące aspekty nauczania filozofa.

\section{PODZIAŁ NATURY I STWORZENIE W PRYMORDIALNYM CZŁOWIEKU}

System filozoficzny Jana Szkota Eriugeny zakłada czwórpodział rzeczywistości (niestworzonej i stworzonej), określonej niezdefiniowanym przez autora pojęciem natura ${ }^{4}$. Natura niestworzona to: a) niestworzona natura stwarzająca - Bóg jako Stwórca wszystkiego, b) niestworzona natura niestwarzająca - Bóg po powrocie stworzenia do Stwórcy. Natura stworzona to: a) stworzona natura stwarzającaprymordialne (pierwotne, wzorcze) przyczyny, b) stworzona natura niestwarzająca - człowiek (natura ludzka). Czwórpodział natury wskazuje, że fundamentalnym aktem stworzenia było powołanie do istnienia stworzonej natury stwarzającej - prymordialnych przyczyn. Źródłem tej natury jest Boża mądrość - Syn Boży, odwieczny Logos, Boże Słowo: „Ojciec w swoim Słowie wszystko uczynił”. W zrodzonym Synu - Bogu zostają powołane do istnienia prymordialne przyczyny - byty wieczne wiecznością Logosu i trwałe Jego trwałością. W Logosie, jako stworzona natura stwarzająca, zaistniał również prymordialny człowiek - bliski aniołom, duchowy, czysty intelekt

sporu nie rozstrzygnięto. Papież Leon IX w 1050 roku potępił Periphyseon. Papież Honoriusz III w 1225 roku skazał dzieło Eriugeny na spalenie. Zob. Breviarium Fidei, Wybór doktrynalnych wypowiedzi Kościoła, oprac. S. Głowa, I. Bieda, Księgarnia św. Wojciecha, Poznań 1997, 304-306; A. Kijewska, Eriugena, Seria Myśli i ludzie, wyd. 1, Wydawnictwo Wiedza Powszechna, Warszawa 2005, 19; Jan Szkot Eriugena, Komentarz do Ewangelii Jana z Homilią do Prologu Ewangelii Jana, tłum. z łac. A. Kijewska, ANTYK, Kęty 2000, 7-8.

3 Benedykt XVI, Jan Szkot Eriugena, Audiencja Generalna 10 czerwca 2009 roku, L'Osservatore Romano (2009)9.

4 Zob. A. Kijewska, Neoplatonizm Jana Szkota Eriugeny, Redakcja Wydawnictw Katolickiego Uniwersytetu Lubelskiego, Lublin 1994, 105.

5 Jan Szkot Eriugena, Periphyseon, Księga II, przełożyła, wstępem i komentarzami opatrzyła A. Kijewska, Wydawnictwo Marek Derewiecki, Kęty 2010, 127. 
z pełnią dostępnej dla ludzkiej natury w stanie raju wiedzy o Bogu i sobie $^{6}$. Zgodnie z objawieniem zawartym w Starym Testamencie ${ }^{7}$ oraz tradycją chrześcijańską potwierdzoną przez Tertuliana ${ }^{8}$, św. Teofila9 i św. Augustyna ${ }^{10}$, Eriugena przyjął prawdę o stworzeniu przez Boga wszystkiego $z$ niczego. W autorskim systemie filozoficznym wskazał, że nicość, z której Bóg stworzył wszystko, jest źródłem „wszystkich rzeczy, które nie jest jednak dostępne żadnemu intelektowi i dlatego nazywane jest Nicością, zgodnie z pierwszym rozumieniem nie-bytu, które zostało zaproponowane w księdze pierwszej"11. Dla Eriugeny Bóg jest Niebytem i wszystko, co wymyka się ludzkiemu poznaniu, również pozostaje niebytem. Do niebytu należy zaliczyć także nicość, z której powstało wszystko, a którą należy rozumieć jako wymykającą się ludzkiemu intelektowi pełnię nieograniczonej i wiecznej jasności dobroci Boga ${ }^{12}$. Wśród prymordialnych przyczyn powołanych do istnienia przez Boga stworzony został także doskonały, duchowy - prymordialny człowiek, który

6 Zob. Eriugena, Periphyseon, Księga IV, przełożyła, wstępem i komentarzami opatrzyła A. Kijewska, Wydawnictwo Marek Derewiecki, Kęty 2012, 169; D. Moran, The Philosophy of John Scottus Eriugena. A Study of Idealism in the Middle Ages, Cambridge University Press, Cambridge 1989, 160 i następne.

7 Zob. 2 Mch 7, 28; skróty i cytaty ksiąg biblijnych wg: Pismo Święte Starego i Nowego Testamentu w przekładzie z języków oryginalnych, opracował Zespół Biblistów Polskich z inicjatywy Benedyktynów Tynieckich, wyd. 5, Pallottinum, Poznań 2000.

8 Zob. A.M. Filipowicz, Wieczność materii w kontekście polemiki Tertuliana z Hermogenesem, w: Ks. Józef Marceli Dołęga - pokorny uczony, człowiek o wielkim sercu. Księga jubileuszowa, red. J. Sokołowski, Wydawnictwo UKSW, Warszawa 2010, 99-113; A.M. Filipowicz, Tertulian przeciwko Hermogenesowi, czyli spór o stworzenie świata, Wydawnictwo Naukowe UKSW, Warszawa 2018.

9 Zob. Katechizm Kościoła Katolickiego, nr 296, Pallottinum, Poznań 1994.

10 Zob. Św. Augustyn, Przeciwko manichejczykom komentarz słowny do Księgi Rodzaju, w: Pisma egzegetyczne przeciw manichejczykom, tłum. z łac. J. Sulowski, ATK, Warszawa 1980, s. 25-29 oraz tamże, Niedokończony komentarz słowny do Księgi Rodzaju, 87-89.

11 Zob. Jan Szkot Eriugena, Periphyseon, Księga I, przełożyła, wstępem i komentarzami opatrzyła A. Kijewska, Wydawnictwo Marek Derewiecki, Kęty 2009, 63.

12 Zob. Jan Szkot Eriugena, Periphyseon, Księga III, przełożyła, wstępem i komentarzami opatrzyła A. Kijewska, Wydawnictwo Marek Derewiecki, Kęty 2009, 239. 
posiadał prawie anielską naturę i jako czysty intelekt otrzymał od Boga stosowną dla swej natury pełnię wiedzy o Stwórcy i o sobie ${ }^{13}$. Prymordialny człowiek wiedział, że pełna wiedza (w sensie absolutnym) o Bogu i o sobie jest dla ludzkiego intelektu, z woli Stwórcy, niedostępna. Naturalnym środowiskiem dla stworzonego człowieka jest stan raju, wyznaczany przez granice ludzkiej natury. Eriugena pisze: „Wyobraź sobie zatem, że krańce ludzkiej natury są jakby dolnymi i górnymi granicami jakiegoś raju, poza którymi nie pojmuje się żadnej stworzonej natury"14. Prymordialny człowiek spełniał wolę Boga, posiadał wiedzę i moc ${ }^{15}$ oraz wolną wolę. Doskonały człowiek pragnął tylko dobra ${ }^{16}$. W Bogu-Logosie zostały powołane do istnienia wszystkie przyczyny prymordialne, co oznacza, że zaistniało całe doskonałe stworzenie, jednak człowiek został wyróżniony spośród stworzenia w ten sposób, iż tylko o nim Biblia mówi, że został stworzony na obraz samego Stwórcy: „rzekł Bóg: Uczyńmy człowieka na Nasz obraz, podobnego Nam” (Rdz 1, 26) oraz „Stworzył więc Bóg człowieka na swój obraz, na obraz Boży go stworzył” (Rdz 1, 27). Stworzony na Boży obraz człowiek został powołany do istnienia, by w granicach raju jako doskonały byt świadczyć o dobroci Boga, ponieważ tam, „gdzie stwarzany jest obraz, tam bardzo wyraźnie ukazuje się Pierwowzór tego obrazu"17. Według Eriugeny, niedefiniowalny w swej istocie człowiek, który powinien zawsze być obrazem samego Boga Stwórcy ${ }^{18}$, jest „pewnym intelektualnym pojęciem odwiecznie ukształtowanym w Bożym Umyśle"19. Eriugena przyjmuje, że wyjątkowość człowieka pośród reszty stworzenia wynika również

13 Zob. Eriugena, Periphyseon, Księga IV, dz. cyt., 169; D. Moran, dz. cyt., 160 i następne.

14 Eriugena, Periphyseon, Księga IV, dz. cyt., 307-309.

15 Zob. tamże, 169-171.

16 Zob. tamże, 221; D. Moran, dz. cyt., 163-165.

17 Eriugena, Periphyseon, Księga IV, dz. cyt., 195.

18 Zob. tamże, 101-103.

19 Tamże, 139. 
z faktu, że właśnie w doskonałej (prymordialnej) ludzkiej naturze Bóg z nicości uczynił wszystko.

W człowieku zawarta została cała rzeczywistość stworzona, ponieważ człowiek: „pojmuje jak anioł, rozumuje jak człowiek, odczuwa jak nierozumne zwierzę, żyje jak roślina, istnieje w ciele i duszy: ma zatem udział we wszelkim stworzeniu, ponieważ poza nim nie znajdziesz żadnego stworzenia"20. Dla wszystkich stworzeń natura ludzka jest pośrednikiem, „w niej bowiem łączą się one ze sobą nawzajem i z wielości tworzą jedno. Jako że nie ma żadnego stworzenia od najwyższego po najniższe, którego nie dałoby się odkryć w człowieku (...). Gdyż w nim schodzi się wszystko, co zostało przez Boga stworzone, i z różnych natur, niby z jakichś odległych dźwięków tworzy jedną harmonię"21. Człowiek jest tyglem, w którym całe stworzenie stapia się w jedną całośćc ${ }^{22}$. Ludzka natura jest uporządkowanym kosmosem i małym wszechświatem. Człowiek to mikrokosmos, którego największą chlubą winien być fakt stworzenia na obraz Boga ${ }^{23}$ w Bogu-Logosie. Według Eriugeny człowiek dosłownie pośredniczył w Boskim akcie stworzenia, ponieważ Stwórca najpierw w ludzkim umyśle stworzył wszystkie rzeczy, a następnie stały się one dla ludzkiej natury przedmiotami poznania i zostały przez człowieka nazwane. Człowiek zapanował nad nazwanym stworzeniem zgodnie z zapisem Księgi Rodzaju (zob. Rdz 1, 28; 2, 19-20). Przez pośrednictwo w stworzeniu człowiek również stał się podobny do Boga. W umyśle człowieka Bóg złożył pojęcia (prawdziwą substancję stworzenia), które jako poznane przez człowieka zostały przez tegoż nazwane, natomiast pojęcie człowieka w sposób doskonały istnieje tylko w umyśle samego Boga ${ }^{24}$. Wydaje się, że dla Eriugeny fakt, iż Ksiega Rodzaju opisuje stworzenie człowieka w ostatnim dniu

20 Eriugena, Periphyseon, Księga III, dz. cyt., 399-401.

21 Eriugena, Periphyseon, Księga II, dz. cyt., 59.

22 Zob. Eriugena, Komentarz z Homilia, dz. cyt., 60.

23 Zob. Eriugena, Periphyseon, Księga IV, dz. cyt., 215.

24 Zob. Eriugena, Periphyseon, Księga IV, dz. cyt., 139-141. 
kreacji, jednoznacznie świadczy o tym, iż całe stworzenie mieści się w ludzkiej naturze, która obejmuje i stapia w sobie niczym w jakimś tyglu - mikrokosmosie wszystkie wcześniejsze pozaczasowe dni stwarzania wszystkiego z niczego.

\section{UPADEK STWORZENIA I OBIETNICA POWROTU DO STWÓRCY}

Eriugena przyjmuje, że za upadek człowieka, a wraz z nim całego stworzenia, które w ludzkiej naturze powstało, odpowiada wielki dar, który człowiek otrzymał w postaci wolnej woli. Wolność wyboru, którą Bóg dla ludzkiej natury niejako zaryzykował z nieograniczonej dobroci, spowodowała, że człowiek w taki sposób skorzystał $\mathrm{z}$ otrzymanego daru, iż wygenerował $\mathrm{w}$ swojej naturze nierozumne poruszenie woli, które sprawiło, że umysł człowieka został odwrócony od Stwórcy ${ }^{25}$. Ten błędny wybór - błąd - pierwotna skaza, najczęściej jest określany jako grzech pierworodny, który stał się przyczyną rozpadu ludzkiej natury, istniejącej przed błędnym wyborem w doskonałej jedności ${ }^{26}$. Zło nie posiada fundamentów substancjalnych ${ }^{27}$, więc błędny wybór nie miał substancjalnego źródła w doskonałej ludzkiej naturze, lecz zło wygenerowało się w człowieku, ponieważ w ludzkiej naturze, obdarzonej wolną wolą, istniała możliwość błędu - przyjęcia kłamstwa za prawdę. Ten błąd spowodował dramatyczne przejście doskonałego - prymordialnego człowieka w niedoskonałego - teofanicznego człowieka, który istnieje w stworzonym świecie ${ }^{28}$. Ludzka

25 Zob. tamże, 373.

26 Zob. J. Trouillard, Érigène et la théophanie créatirice, w: The Mind of Eriugena. Papers of Colloquium, Dublin 1970, red. J.J. O'Meara, L. Bieler, Irish University Press, Dublin 1973, 108.

27 Zob. Iohannis Scotti seu Eriugenae, Periphyseon, liber quintus, ed. É. Jeauneau, Corpus Christianorum Continuatio Mediaevalis (CChCM) 165, Brepols, Turnhout 2003, 120-121.

28 Zob. F. Bertin, Les origines de l'homme chez Jean Scot, w: Jean Scot et l'histoire de la philosophie. Colloque du C.N.R.S., Laon jiullet 1975, red. R. Roques, Bontemps Limoges, Paris 1977, 307-308. 
natura zaistniała w podziale płciowym ${ }^{29}$, w czasie i przestrzeni, które w rzeczywistości prymordialnej zostały przewidziane tylko jako możliwość - nie jako konieczność. Absolutnie doskonały Bóg stworzył doskonały prymordialny świat, złożony z bytów trwałych, natomiast teofaniczny człowiek chce naśladować Boga w akcie stwórczym i buduje nietrwały, zmienny świat bytów zmysłowych ${ }^{30}$. Wydaje się, że Eriugena dopuszcza również, że Bóg mógł przewidzieć upadek stworzenia, więc ustanowił zmysłowy świat, by wyznaczyć naturze ludzkiej szlak powrotu do pierwotnej jedności ${ }^{31}$. Błędny wybór ludzkiej natury jest przyczyną upadku człowieka i stworzenia, lecz Stwórca nie potępia tego, którego powołał do istnienia na swój obraz i podobieństwo. Eriugena przyjmuje, że zgodnie z zapisem w Księdze Rodzaju błąd (grzech) przedostał się do umysłu (mężczyzny) wówczas, gdy umysł uległ podszeptom zmysłu (kobiety). W zmyśle tkwiła możliwość pragnienia rozkoszy i to pragnienie stało się jak przebiegły wąż, który sugerował coś umysłowi. Umysł miał strzec Bożego porządku - raju - i pilnować zmysłów. Stwórca ma więc pretensje do umysłu i do zmysłu, lecz nie przeklina, nie potępia i nie złorzeczy im (zob. $\operatorname{Rdz} 3,12)$. Dramatyczne słowa padają wówczas, gdy Stwórca zwraca się do węża (pragnienia): „Ponieważ to uczyniłeś, bądź przeklęty” (Rdz 3, 14). Bóg potępia źródło zła, które powoduje, że w ludzkiej naturze generuje się sprzeciw wobec woli Stwórcy. Ten sprzeciw jest sprzeczny z pierwotnym aktem stwórczym Boga ${ }^{32}$. Stwórca nie potępił stworzenia i sprawiedliwość ustępuje przed miłosierdziem, gdy absolutnie transcendentny Bóg składa obietnicę powrotu do raju - pierwotnego porządku i doskonałości. Zmysł ludzkiej natury (kobieta) słyszy następujące słowa: „Obarczę cię niezmiernie

29 Zob. É. Jeauneau, La Division des sexes chez Grégoire de Nysse et chez Jean Scot Erigène, w: Eriugena, Studien zu seinen Quellen, red. W. Beierwaltes, C. Winter, Universitätsverla, Heidelberg 1980, 341-364.

30 Zob. Eriugena, Periphyseon, Księga II, dz. cyt., 207-209.

31 Zob. tamże, 81-83.

32 Zob. Eriugena, Periphyseon, Ksiegga IV, dz. cyt., 375. 
wielkim trudem twej brzemienności, w bólu będziesz rodziła, ku twemu mężowi będziesz kierowała swe pragnienia, on zaś będzie panował nad tobą" (Rdz 3, 16). Mężem zmysłu jest w systemie Eriugeny umysł, więc dogodne warunki dla powrotu do utraconego raju ludzkiej natury powstają wówczas, gdy umysł panuje nad zmysłem. Po błędnym wyborze ludzkiej natury, prymordialny świat przeszedł $\mathrm{w}$ istnienie zmysłowe. Eriugena bardzo ostrożnie przyjmuje, że zło jest w pewnym sensie stanem mniejszej (umniejszonej) wiedzy, więc analogicznie zmysłowy świat nie jest rzeczywistością całkowicie negatywną, w której tylko trwa czas kary za błędny wybór. Zmysłowy, teofaniczny świat jest rzeczywistością upadłą w relacji do świata prymordialnego, lecz miłosierny Stwórca właśnie przez ten teofaniczny świat umożliwia ludzkiej naturze powrót do stanu utraconego, udzielając jednocześnie pomocy na tym szlaku. Eriugena przyjmuje, że całe stworzenie składa się z trzech rodzajów natur: a) czyste duchy, b) byty materialne, c) byty łączące w sobie materialność i duchowość (natura ludzka). Wśród trzech natur świat bytów materialnych jest rzeczywistością absolutnie szczególną, ponieważ: a) analiza bytów materialnych często prowadzi do odkrycia właściwego - prawdziwego świata bytów duchowych, b) do tego świata przyszedł Syn Boży odwieczny Logos, c) na tym świecie Boże Słowo stało się ciałem i otwarło naturze ludzkiej bramy raju.

\section{EGZEGETYCZNY KONTEKST POWROTU}

Stworzenie, które zaistniało i upadło w ludzkiej naturze, dzięki wcieleniu, śmierci ciała i zmartwychwstaniu Logosu, otrzymało możliwość powrotu do Stwórcy. Według Eriugeny, warunki i okoliczności powrotu zostały opisane w Biblii, która wskazuje na dwa następujące powroty: a) powrót powszechny, b) powrót wybranych. Nowy Testament w Ewangelii według św. Łukasza zawiera przypowieść o uzdrowieniu dziesięciu trędowatych, z których tylko jeden - obcokrajowiec, Samarytanin - powraca do Jezusa, by podziękować 
za dar zdrowia i wychwala Boga. Oparte na wierze postępowanie Samarytanina zostaje przez Jezusa dodatkowo nagrodzone wyzwoleniem (zob. Łk 17, 11-19). Eriugena przyjmuje, że powracający Samarytanin jest symbolem intelektu, który uświadomił sobie, że został uzdrowiony, więc wychwala Boga i powraca do Jezusa, przez którego uzdrowienie się dokonało. W Samarytaninie powraca również dziewięciu pozostałych uzdrowionych, których ten godny obcokrajowiec reprezentuje. Według Eriugeny Samarytanin jest symbolem całej natury ludzkiej, która na drodze powrotu do Stwórcy stanie się intelektem kontemplującym Boga ${ }^{33}$. Według Eriugeny o powrocie do Stwórcy poucza również przypowieść o pannach z Ewangelii według św. Mateusza. Panny zabrały swoje lampy i wyszły na spotkanie oblubieńca. Wśród dziesięciu panien jedna połowa to panny mądre, natomiast druga to panny głupie. Kryterium oceny wynika z roztropności, która wyraża się odpowiednią zapobiegliwością - panny mądre zabezpieczyły zapas oliwy. Oblubieniec spóźniał się, zapadł zmrok i panny zasnęły. Lampy nieroztropnych panien pogasły, natomiast roztropne nie dzielą się zapasem oliwy z uwagi na troskę o własne lampy. Nieroztropne panny oddalają się, by zakupić oliwę, i w tym właśnie czasie nadchodzi oblubieniec. Panny z zapalonymi lampami wchodzą do weselnej sali i drzwi zostają zamknięte. Nieroztropne panny wracają, lecz oblubieniec nie otwiera drzwi nieznajomym. Święty Mateusz zachęca do ustawicznego czuwania w obliczu faktu, iż nie znamy szczegółowych zamiarów Boga (zob. Mt 25, 1-13), natomiast Eriugena wskazuje, że oblubieńcem jest Jezus, a oblubienicą Kościól. Natura ludzka, która została oznaczona w przypowieści liczbą dziesięć, wychodzi w ruchach umysłu na spotkanie oblubieńca i oblubienicy (Chrystusa i Kościoła). Na spotkanie zmierza cała natura ludzka i właśnie lampy symbolizują naturalne - wrodzone, wszczepione przez Stwórcę pragnienie natury ludzkiej dotyczące wiecznej światłości. Cała natura ludzka - reprezentowana przez wszystkie

33 Zob. Eriugenae Periphyseon, liber quintus, 1020a-1021a. 
dziesięć panien - przychodzi do Jezusa, co oznacza, że wszystkie panny dostępują wrodzonych dóbr charakterystycznych dla natury ludzkiej. Eriugena przyjmuje więc, że dziesięć panien przychodzących do Jezusa symbolizuje powszechny powrót całej ludzkiej natury do Stwórcy. Panny jednak dzielą się na roztropne i nieroztropne (mądre i głupie), co zdaniem Eriugeny jednoznacznie świadczy o tym, iż po powrocie powszechnym nastąpi powrót wybranych, których symbolem są panny roztropne. $Z$ całej ludzkiej natury, a więc spośród wszystkich ludzi, tylko niektórzy dostąpią powrotu wybranych, których reprezentuje pięć panien zaopatrzonych w oliwę czystego sumienia i dobrych czynów. Czyste sumienie i dobre życie prowadzą do Boga, do przebóstwienia - do powrotu wybranych ${ }^{34}$. Eriugena przyjmuje, że cała rodzina ludzka dostąpi powszechnego powrotu do doskonałości i Stwórcy, lecz tylko wybrani dostąpią przebóstwienia. Każdy człowiek powróci do Boga w procesie powrotu powszechnego i wówczas każdy dokona nad sobą ahistorycznego (samo)sądu ostatecznego. Wielu ludzi ograniczy się do cielesnych pragnień i zmysłowych wyobrażeń, które będą już bezpodstawne i niemożliwe do spełnienia wobec faktu, że stworzenie powróci do prymordialnych przyczyn, więc wszystko, co cielesne i zmysłowe, przestanie istnieć. Wydaje się, że właśnie w ten sposób wygeneruje się rzeczywistość piekielna, w której wolna ludzka wola usilnie skieruje się z ogromnym pragnieniem ku czemuś, co już nie istnieje. Eriugena wskazuje, że to straszne cierpienie jest istota piekła ${ }^{35}$, a dodatkowym aspektem tej udręki będzie cierpienie wynikające z pełnej świadomości, iż

34 Zob. tamże, 1011a-1012a; zob. też P. Dietrich, D. Duclow, Paradise and Eschatology: Symbolism and Exegesis in „Periphyseon V”, w: Jean Scot - écrivain, red. G.-H. Allard, Éditions Bellarmin; J. Vrin, Montréal - Paris 1986, 41-43.

35 Zob. Eriugenae Periphyseon, liber quintus, 967a; zob. też B. McGinn, Eriugena Confronts the End, w: History and Eschatology in John Scottus Eriugena and His Time, red. J. McEvoy, M. Dunne, Leuven University Press, Leuven 2002, 28; D. Duclow, P. Dietrich, Hell and Damnation in Eriugena, w: History and Eschatology in John Scottus Eriugena and his time, red. J. McEvoy, M. Dunne, Leuven University Press, Leuven 2002, 356-360. 
zamknięta została możliwość uczestnictwa w powrocie wybranych, dla których przewidziano przebóstwienie i kontemplację prawdy.

\section{PRZEBÓSTWIENIE}

Chrześcijański neoplatonizm Eriugeny oznacza pozaczasowe zrodzenie Logosu i ustanowienie w Nim prymordialnych przyczyn reszty stworzenia. Celem istnienia stworzenia jest powrót do Boga-Logosu, przebóstwienie i pozaczasowe trwanie w Bogu. Charakterystyczny dla Plotyna neoplatoński schemat trwania, wylewu i powrotu zostaje przez Jana Szkota dostosowany do chrześcijaństwa poprzez przyjęcie wylewu stworzenia z Boga za pośrednictwem Boga-Logosu; procesu powrotu stworzenia do Logosu; przebóstwienia i rajskiego trwania w Bogu po powrocie. Dostosowując schemat trwania, wylewu i powrotu do koncepcji chrześcijańskiej, Eriugena dokonuje przesunięcia trwania $z$ początku na koniec oraz przesunięcia procesu powrotu z końca do etapu pośredniego. Po przejściu tej drogi stworzenie wróci do swego źródła, by spocząć w nim i trwać36. Stworzenie wszystkiego $\mathrm{z}$ niczego dokonało się poza czasem i przestrzenią w rzeczywistości ahistorycznej, więc powrót wszystkiego do źródła również dokona się w tej rzeczywistości. Schemat wylewu, powrotu i trwania zamyka całą rzeczywistość, a jednocześnie jest adekwatną analogią do schematu ludzkiego myślenia. Wszystko, co historyczne, musi się skończyć, ponieważ to, co miało początek, musi również mieć swój $\mathrm{kres}^{37}$. W Apokalipsie święty Jan pisze: „I ujrzałem niebo nowe i ziemię nowq, bo pierwsze niebo i pierwsza ziemia przeminęły, i morza już nie ma" (Ap 21, 1). Dosłowna interpretacja tych słów jednoznacznie, zdaniem Eriugeny, wskazuje na kres wszystkiego, co miało

36 Zob. S. Gersh, From Iamblichus to Eriugena. An Investigation of the Prehistory and Evolution of the Pseudo-Dionysian Tradition, Brill, Leiden 1978, 220 i następne.

37 Zob. Eriugenae Periphyseon, liber quintus, 890b-891b. 
swój początek ${ }^{38}$. Eriugena poddaje również dosłownej interpretacji fragment Ewangelii, w którym święty Mateusz pisze: „Zaraz też po ucisku owych dni stonce się zaćmi i księżyc nie da swego blasku; gwiazdy zaczna spadać z nieba i moce niebios zostaną wstrząśnięte” (Mt 24, 29). Zapowiadane dni ucisku będą - według Eriugeny - wydarzeniami historycznymi ${ }^{39}$. Na szczególną uwagę wydaje się zasługiwać fakt, iż Jan Szkot, uchodzący za mistrza egzegezy alegorycznej, dokonuje $\mathrm{w}$ przedmiotowej kwestii interpretacji literalnej biblijnego tekstu. Eriugena przyjmuje, że początkiem, powszechnym celem i końcem stworzenia jest Logos - Słowo Boże. Przyjmuje nawet, że początek i koniec stworzenia są Słowem, które samo jest końcem bez końca i początkiem bez początku, poza Ojcem ${ }^{40}$, z którego Słowo jest zrodzone. Przejście $\mathrm{z}$ istnienia teofanicznego do prymordialnego nie wynika z wysiłku, czy inicjatywy ludzkiej natury, lecz z zejścia Logosu do poziomu człowieka teofanicznego i odkupienia ludzkości, co umożliwia jej i całemu stworzeniu powrót do Ojca. W Komentarzu do Ewangelii Jana Eriugena zwraca uwagę, że wyjściem Logosu od Ojca jest przyjęcie ludzkiej natury, natomiast powrót do Ojca to przebóstwienie i wyniesienie przyjętej natury do boskości. Logos sam zstąpił i stał się człowiekiem, by wybawić tych, dla których zstąpił. Logos sam wstąpił do Ojca, lecz ci, których wybawił, mogą w sposób duchowy przez wiarę i nadzieję razem z Logosem wstępować do Ojca, co jest zapowiedzią rzeczywistego wstąpienia, które dokona się na końcu czasów „zgodnie z tym, co mówi Jan w swoim liście »obecnie jesteśmy dziećmi Bożymi, ale jeszcze się nie ujawniło, czym będziemy. Wiemy, że gdy się objawi, będziemy do Niego podobni, bo ujrzymy Go takim, jakim jest « (1J 3,2). Dlatego [Chrystus] sam zstąpił i sam wstąpił, gdyż On sam ze wszystkimi swoimi członkami jest

38 Zob. Eriugenae Periphyseon, liber quintus, 891c; zob. też B. McGinn, Eriugena Confronts the End, art.cyt., 15 i następne.

39 Zob. Eriugenae Periphyseon, liber quintus, 996a.

40 Zob. tamże, 893a. 
jednym Bogiem, jedynym Synem Bożym. W Nim samym wszyscy, którzy w Niego wierzą, są jednym. Jeden więc Chrystus, ciało wraz z członkami, wstąpił do Ojca"41.

Wydaje się, że dla Eriugeny wcielenie Logosu jest końcem działania Boga Stwórcy i początkiem działania Boga Zbawcy ${ }^{42}$. Chrystus jest Bogiem-Logosem, Słowem i Synem, który stał się człowiekiem i zmarł oraz zmartwychwstał, by dokonać odkupienia stworzenia, więc wcielenie, śmierć i zmartwychwstanie stają się warunkami powrotu człowieka do Stwórcy, a to oznacza, że stanowią również zapowiedź tego, czego doświadczy ludzka natura na końcu czasów. Chrześcijanin doświadcza aktualnie (w doczesnym życiu) tego wszystkiego poprzez wiarę, natomiast żyje nadzieją, że u kresu teofanicznej rzeczywistości doświadczy tego wszystkiego w realnym i doskonałym widzeniu. Stworzenie powróci do Stwórcy, a naturalną zapowiedzią tego powrotu są liczne procesy cykliczne zachodzące w świecie przyrody i w budowaniu ludzkiej wiedzy. Świat przyrody dąży do kresu, który jest jego początkiem, a proces ten dotyczy całego wszechświata ${ }^{43}$. Człowiek w dążeniu do wiedzy posługuje się dialektyką i operując pojęciem istoty poszukuje jej poznania analogicznie do procesów zachodzących $\mathrm{w}$ geometrii i arytmetyce ${ }^{44}$. Wydaje się, że przesłanie płynące $\mathrm{z}$ wymienionych procesów jest jednak tylko ukrytą formą pewnej zapowiedzi, która może, lecz nie musi się dokonać, ponieważ powrót stworzenia do źródeł jest sprawą znacznie istotniejszą niż pory roku czy ruch planet. Warunkiem tego powrotu jest Boża łaska, która znalazła swój najdoskonalszy wyraz w Jezusie Chrystusie. Stworzenie może powrócić do źródła, ponieważ zawsze istnieje odwieczny Logos, w którym ono zaistniało, w sposób właściwy i trwały. Skutki przyczyn prymordialnych mają gdzie wracać,

41 Eriugena, Komentarz z Homilia, dz. cyt., 100-101.

42 Zob. D. Duclow, Dialectic and Christology in Eriugena's Periphyseon, Dionysius 4(1980), 110.

43 Zob. Eriugenae Periphyseon, liber quintus, 866c-d.

44 Zob. tamże, 869a-c. 
ponieważ Bóg w zrodzonym Logosie ustanowił wieczne przyczyny, których skutki są trwałe ich trwałością, podobnie jak przyczyny są wieczne wiecznością nie własną, lecz zrodzonego z Boga-Logosu. Skoro jednak skutki mają powrócić do prymordialnych przyczyn, rodzi się pytanie, co z tym wszystkim, co np. składało się na ludzkie życie w teofanicznej rzeczywistości. Eriugena przyjmuje, że ludzkie ciało posiada niezmienny i trwały element, którym jest duchowe ciało, zawierające w sobie formę duszy. Tak jak w geometrii znak trójkąta jest tylko znakiem, a nie trójkątem samym w sobie, tak również materialne ludzkie ciało jest tylko znakiem ciała duchowego. Śmierć człowieka powoduje, że materialne ciało zmierza ku materii i rozpada się na elementy, natomiast nie znosi to w żadnej mierze zapowiedzi zmartwychwstania, ponieważ w ludzkiej duszy została utrwalona forma materialnego ciała, więc zmartwychwstanie jest jak najbardziej realną rzeczywistością i aktualną obietnicą ${ }^{45}$. Skutki przyczyn nie zostały zwolnione z wysiłku należytej troski o rozwój duchowy, etyczny i intelektualny, więc powrót do przyczyn nie oznacza unicestwienia wykonanej pracy, lecz stanowi pewną wartość dodaną w postaci tego wszystkiego, co w procesie rozwoju zostało dokonane i osiągnięte. $\mathrm{W}$ pewnym sensie, w wyniku powrotu przyczyna zostanie niejako wzbogacona o pozytywny dorobek jej skutku ${ }^{46}$. Wzbogacenie przyczyny o dorobek skutku wydaje się szczególnie ciekawym zagadnieniem, zwłaszcza w kontekście doskonałości samej przyczyny, która została jako doskonała ustanowiona w wiecznym Bogu-Logosie, a jednocześnie Eriugena dopuszcza możliwość udoskonalenia jej poprzez wysiłek jej skutku, dokonany w niedoskonałej rzeczywistości. Wydaje się, że Eriugena dopuszcza (w pewnym sensie) udoskonalenie przez człowieka teofanicznego człowieka prymordialnego,

45 Zob. Eriugena, Periphyseon, Księga IV, dz. cyt., 237-239.

46 Zob. S. Gersh, The Structure of Return in Eriugena's Periphyseon, w: Begriff und Metapher. Sprachform des Denkens bei Eriugena, red. W. von Beierwaltes, C. Winter, Heidelberg 1990, 113-114. 
stworzonego przez transcendentalnego Boga - Stwórcę, co może stanowić przyczynek do bardziej wnikliwego badania tej problematyki. Wydaje się również, iż Eriugena przyjmuje, że substancja rzeczy nie ulegnie unicestwieniu, lecz zostanie przemieniona w coś lepszego. Oznacza to, że w procesie powrotu wszystkiego do źródła zaistnieje prosta i wieloraka jednośćc ${ }^{47}$, a więc zaistnieje coś, czego zrozumienie całkowicie przewyższa możliwości ludzkiego intelektu w okowach świata teofanicznego.

Całe stworzenie powstało w ludzkiej naturze, więc pierwszy etap powrotu zostanie najpierw poprzedzony zmartwychwstaniem, w wyniku którego zostanie zniesiony podział na płeć żeńską i męską, co oznacza, że zaistnieje człowiek w formie prostszej, a więc doskonalszej, bo zjednoczonej. Dla zjednoczonego człowieka dokona się drugi etap poprzez wejście ziemskiego kręgu w bramy raju, co oznacza powrót upadłego świata do rajskiej rzeczywistości. W raju zaistnieją warunki dla trzeciego etapu, w którym ziemskie byty zaistnieją jako byty niebieskie. Następnie dojdzie do etapu czwartego, w którym stworzenie zmysłowe przekształci się w inteligibilne, co z kolei umożliwi dokonanie się ostatniego - piątego etapu, w którym dojdzie do przedziwnego zjednoczenia stworzenia i Stwórcy, przy jednoczesnym zachowaniu nie dającej się nigdy znieść fundamentalnej różnicy między Bogiem i stworzeniem. Kres niewidzialnych i widzialnych rzeczy nastąpi, gdy najpierw przekształcą się one w byty inteligibilne, by następnie bez utraty swej istoty, swej substancji i bez zmieszania dostąpić wniknięcia w samego Boga ${ }^{48}$. Zgodnie $\mathrm{z}$ założeniem, że każdy skutek jest o tyle trwały, o ile posiada trwałą przyczynę, i na ile uczestniczy w tej przyczynie, na każdym z etapów powrotu skutek wnika w przyczynę, powraca do niej niejako oczyszczony z tego, co dla doskonalszego istnienia zbędne, lecz nie pozbawiany swej substancji, co oznacza, że byty, które dostąpią wniknięcia w Boga,

47 Zob. Eriugenae Periphyseon, liber quintus, 876b.

48 Zob. tamże, 893d-894a. 
nie rozproszą się $\mathrm{w}$ nieograniczonej transcendencji, lecz zachowując swoją substancję, zaistnieją w Bogu bez wcześniej posiadanych niedoskonałości.

Eriugena dokonuje wyraźnego rozróżnienia między powszechnym powrotem, określonym jako reditus generalis, a powrotem, którego dostąpią wybrani. Powrót wybranych Jan Szkot określa jako reditus specialis. Wszystkie zmysłowe byty zostały pierwotnie ustanowione jako doskonałe stworzenie, istniejące $\mathrm{w}$ jedności prymordialnych przyczyn, więc pierwszy etap powszechnego powrotu będzie polegał na powrocie zmysłowych bytów do swoich przyczyn. Drugi etap powszechnego powrotu dotyczy bezpośrednio natury ludzkiej, dla której ofiara Chrystusa otworzyła bramy raju. Zbawienie ludzkości umożliwia realizację drugiego etapu, który polega na powrocie ludzkiej natury do pierwotnego stanu podobieństwa do Boga - do pierwotnego Bożego obrazu. Ponieważ Chrystus zbawił wszystkich ludzi, to każdy człowiek dostąpi uczestnictwa w utraconym niegdyś, Bożym podobieństwie. Niezależnie od jakości doczesnego życia w świecie, każdy człowiek odzyska godność Bożego obrazu, ponieważ godność ta wynika nie z ludzkich zasług, lecz z pierwotnego zamierzenia samego Boga oraz z ofiary zbawczej Chrystusa. Przeznaczeniem ludzkiej natury był stan, który symbolicznie zostaje określony jako raj, więc odzyskując godność Bożego obrazu, każdy człowiek i cała ludzkość powróci do raju. W ten sposób dojdzie do wprowadzenia naturalnego porządku wynikającego z prazamiarów Boga i jednocześnie z obejmującej wszystkich ofiary Bożego Syna. Pierwotny porządek został zburzony przez błąd - grzech. Niezliczone ludzkie grzechy wymagały ofiary Chrystusa, więc skutki grzechu Eriugena wprowadza niejako w bramy raju, ponieważ przyjmuje, iż wszyscy ludzie dostąpią godności Bożego obrazu, a więc dostąpią rzeczywistości raju, lecz nie każdy, a tylko niektórzy, będą mogli sporzywać owoce z Drzewa Życia. Dostąpienie rajskiej rzeczywistości nie jest, według Eriugeny, jednoznaczne z możliwością korzystania z owoców Drzewa Życia, które według filozofa należy utożsamiać 
z kontemplacją prawdy, wiecznym pokojem, wiecznym szczęściem i przebóstwieniem ${ }^{49}$. Trzeci etap powrotu dotyczy właśnie przebóstwienia - deifikacji, której dostąpią tylko wybrani, a więc ten etap jest tylko o tyle elementem powrotu powszechnego, o ile spośród wszystkich, którzy dostąpią raju, tylko niektórzy dostąpią owoców z Drzewa Życia. Warunkiem deifikacji jest łaska Zbawiciela, która może sprawić, iż wybrani dostąpią przedarcia się przez okowy naturalnych praw i pradawnych ograniczeń ludzkiej natury, by osiągnąć zjednoczenie z Bogiem. Przebóstwienie jest procesem, który według Eriugeny składa się z siedmiu następujących etapów: ludzkie ciało przechodzi w życiowy ruch, życiowy ruch przechodzi w zmysł, zmysł przechodzi w rozum, który przechodzi w ducha, co oznacza koniec istnienia rozumnego stworzenia. Przekształcenie rozumu w ducha jest ostatnim etapem powrotu powszechnego. Ludzka natura zostaje zjednoczona w intelekcie i po czterech etapach kończy się powrót powszechny. Następne trzy etapy dotyczą powrotu wybranych ${ }^{50}$. Piąty etap powrotu to proces przejścia ducha w wiedzę. Etap ten dotyczy wiedzy o wszystkim, co znajduje się poniżej poziomu samego Boga w ontologicznej strukturze rzeczywistości. Szósty etap to przemiana wiedzy w mądrość, którą Eriugena utożsamia w tym kontekście z kontemplacją prawdy. Ostatni - siódmy etap oznacza najbardziej tajemnicze, niepojmowalne w pełni dla ludzkiego intelektu przejście czystych duchów w Boga.

Powrót powszechny zakończy się przemianą rozumu w ducha i dla wybranych rozpocznie się proces przebóstwienia ${ }^{51}$. (Samo)sąd ostateczny skieruje wybranych ku Bogu i intencjonalnie dostąpią oni zjednoczenia $\mathrm{z}$ Bogiem. Stanie się to $\mathrm{w}$ procesie przemieniania się intelektu w to, co będzie przedmiotem jego poznawania. Intelekt będzie poznawał Boga i będzie się w tym procesie jednoczył z Bogiem.

49 Zob. tamże, 979a-b.

50 Zob. tamże, 874b.

51 Zob. tamże. 
Tak pojęte przebóstwienie będzie wiecznym szczęściem kontemplacji prawdy. Intelekt będzie kontemplował Boga i w tym procesie będzie poznawał Go, co według Eriugeny oznacza, że intelekt będzie stawał się bogiem ${ }^{52}$. Ten proces będzie możliwy, ponieważ możliwe jest jednoczenie się duchowych natur. Efektem tego procesu nie będzie jednak jakikolwiek nowy, złożony z Boga i intelektu byt. Duchowe natury osiągną stan jedności bez wygenerowania nowej, złożonej całości. Ten proces będzie możliwy również dlatego, że duchowe natury posiadają zdolność jednoczenia się bez naruszania niezmiennych, własnych form ${ }^{53}$.

Wydaje się, że należy zwrócić szczególną uwagę, zwłaszcza w kontekście wielowiekowych oskarżeń Jana Szkota o panteizm, że w koncepcji procesu przebóstwienia Eriugena nie dopuszcza panteistycznego zjednoczenia natur, lecz wskazuje na przeciwieństwo panteizmu, ponieważ duchowe formy, pomimo zjednoczenia, zachowują odrębność, co jest przeciwieństwem panteistycznego pomieszania natur. Koncepcja Eriugeny wyklucza zniesienie fundamentalnej różnicy zachodzącej pomiędzy Stwórcą i stworzeniem, co oznacza, że zniesienie odrębności w zjednoczeniu natur również jest wykluczone, a to wyklucza panteizm. Można podnieść kwestię, czy koncepcja Eriugeny jest w ogóle możliwa - czy możliwe jest przebóstwienie stworzenia bez pomieszania natur i zachowanie pełnej odrębności form jednoczących się w przebóstwieniu elementów. Eriugena zakłada, że zachodzi taka możliwość, ponieważ mamy do czynienia z nieograniczonym Bogiem, a ta możliwość nie wynika ze zdolności własnych stworzenia, lecz z woli i łaski Boga. Intelekt w procesie kontemplacji będzie poznawał Boga, a tym samym będzie jednoczył się z Nim - będzie stawał się bogiem, lecz nawet sam Bóg nie poznaje w pełni siebie, bo wówczas mógłby zamknąć siebie w okowach definicji, co spowodowałoby, że owa definicja wyznaczyłaby

52 Zob. Eriugena, Periphyseon, Księga I, 85-87.

53 Zob. Eriugenae Periphyseon, liber quintus, 881a-b. 
granice Boga, który w swej transcendencji pozostaje nieograniczony. Stworzenie będzie więc poznawać Boga, lecz nigdy nie pozna Go $\mathrm{w}$ sensie absolutnym. Boża wola i łaska stanowią warunek konieczny dla przebóstwienia, którego przykładem w egzegezie Eriugeny jest Jan Chrzciciel. W Homilii do Prologu Ewangelii Jana Eriugena pisze: „Przeto Poprzednik Pański był człowiekiem, nie bogiem. Pan zaś, którego był on Poprzednikiem, był zarazem człowiekiem i Bogiem. Poprzednik był człowiekiem, który za sprawą łaski miał stać się bogiem. Ten, którego poprzedzał, był Bogiem ze swej natury, który w swym uniżeniu miał przyjąć człowieczeństwo dla naszego zbawienia i odkupienia" ${ }^{54}$. Boża łaska wspiera intelektualną i moralną aktywność ludzkiej natury, więc człowiek otwarty na działanie tej łaski może dostąpić intelektualnego oświecenia, które stanowi przygotowanie do kontemplacji prawdy i przebóstwienia. Na płaszczyźnie moralnej łaska znosi ludzkie grzechy. W Periphyseonie Eriugena pisze: „Otóż Ojciec jest zarazem światłem, ogniem i ciepłem, i Syn jest światłem, ogniem i ciepłem oraz Duch Święty jest ogniem, światłem i ciepłem, ponieważ oświeca Ojciec, oświeca Syn, oświeca Duch Święty. Oni sami udzielają bowiem wszelkiej wiedzy i mądrości. Spala Ojciec, spala Syn, spala Duch Święty, gdyż jednocześnie niszczą nasze przewinienia, a nas, niby jaką̧ś ofiarę całopalną, przywracają do jedności ze sobą poprzez theosis to jest przebóstwienie ${ }^{55}$. Boża łaska jest darem Stwórcy dla człowieka. W zależności od zdolności przyjęcia tego daru i intelektualnego zrozumienia, aniołowie i ludzie w różnym stopniu uczestniczą w łasce. Zdolnością przyjęcia łaski jest pojemność intelektu i otwartość - miara tej otwartości, którą Eriugena za Pseudo Dionizym Areopagitą nazywa analogią ${ }^{56}$, z której wynika porządek rzeczywistości stworzonej, oparty na strukturze hierarchicznej. Porządek stanowi źródło harmonii różnych rzeczy,

54 Eriugena, Komentarz z Homilią, dz. cyt., 57.

55 Eriugena, Periphyseon, Księga IV, 59.

56 Zob. Eriugenae Periphyseon, liber quintus, 905b. 
które zostały zestrojone w jedną rzeczywistość stworzoną ${ }^{57}$. Według Eriugeny ludzie i ich „intelekty nie są czymś od siebie różnym, jako że prawdziwą i najwyższą naszą istotą jest intelekt uszczegółowiony kontemplacją prawdy" 58 . Oznacza to, że nawet po przejściu rzeczywistości zmysłowej w rzeczywistość duchową nie dojdzie do zniesienia jednostkowości i ujednolicenia wszystkiego. Ludzka jednostkowość po zaniku rzeczywistości zmysłowej zostanie oparta na indywidualnej otwartości i zdolności do przyjęcia łaski. O ludzkiej jednostkowości w rzeczywistości duchowej będzie decydować analogia - miara otwartości na łaskę i pojemność intelektu. Bóg jest absolutnie transcendentny i nie zachodzi możliwość wpływu, a tym bardziej umniejszenia transcendencji Boga, więc również to, co niedoskonały ludzki język ujmuje jako zjednoczenie stworzenia ze Stwórcą, takiego wpływu mieć nie może.

W kontekście absolutnej transcendencji Boga naturalne wydaje się pytanie: czym będzie przebóstwienie, skoro w swej istocie Bóg Stwórca jest poza zasięgiem człowieka i każdego bytu stworzonego? Eriugena przyjmuje, że szczęśliwa wizja kontemplacji i przebóstwienia dokona się poprzez teofanię ${ }^{59}$, o czym poucza święty Paweł: „Teraz widzimy jakby w zwierciadle, niejasno; wtedy zaś [ujrzymy] twarzą w twarz" (1 Kor 13, 12). Oznacza to, że ludzkiemu intelektowi objawia się Boska twarz - moc Boga, która z natury jest niedostępna ${ }^{60} \mathrm{dla}$ stworzenia, co oznacza, że również w rzeczywistości ostatecznej ten fakt będzie miał decydujący wpływ na jakość i formę kontemplacji, w której intelekt natury ludzkiej będzie poznawał nieskończonego Boga. Kontemplacja oznacza poznawanie niezapośredniczone, a więc bezpośrednie. Kontemplacja Boga w stanie przebóstwienia oznacza więc taki proces, w którym między poznającym i poznawanym nie

57 Zob. Eriugenae Expositiones in Ierarchiam Coelestem, red. J. Barbet, Brepols, Turnhout 1975, 138.

58 Eriugena, Periphyseon, Księga IV, dz. cyt., 177.

59 Zob. Eriugenae Periphyseon, liber quintus, 963c.

60 Zob. Eriugenae Periphyseon, liber quintus, 926c-d. 
istnieje żaden pośrednik. Pomiędzy Bogiem i intelektem w stanie przebóstwienia, w procesie kontemplacji Boga nie będzie żadnego innego stworzenia ${ }^{61}$, będzie tylko bezpośrednia relacja pomiędzy transcendentnym Stwórcą i stworzeniem - ludzkim intelektem. Sytuacja ta nie oznacza jednak, że Bóg jest czymkolwiek ograniczony i nie może posługiwać się wybraną teofanią dla objawiania samego siebie. Często tak czyni, ponieważ wybrana przez Boga teofania w określonej sytuacji staje się najbardziej dogodna dla ludzkiego intelektu, zwłaszcza gdy chodzi o szczegółowe aspekty realizacji Bożych planów. Najdoskonalszą teofanią jest oczywiście sam Bóg - zrodzony Syn - odwieczny Logos - Jezus Chrystus - wcielone Słowo Boga. Przed przyjęciem ciała z ludzkiej Matki, Syn Boży pozostawał absolutnie poza zasięgiem poznania każdego anioła, człowieka i każdego innego stworzenia. Ludzka Matka, otwarta na wolę Boga, urodziła Bożego Syna, przez którego zaistniało stworzenie. Stworzenie narodziło Stwórcę i przez wcielenie zaistniała najdoskonalsza, przekraczająca jakiekolwiek oczekiwania oczekujących na Boże objawienie teofania, która zaistniała w taki sposób, że wychodząc naprzeciw pragnieniu stworzenia, pozostała otwarta na ludzkie i anielskie poznanie ${ }^{62}$.

\section{ZAKOŃCZENIE}

W systemie filozoficznym Eriugeny absolutnie transcendentny Bóg, istniejący wraz ze zrodzonym Synem - Bogiem-Logosem oraz Duchem Świętym, dokonał stworzenia wszystkiego z niczego, ustanawiając w wiecznym Logosie zależne od Stwórcy przyczyny prymordialne. Według Eriugeny Biblia poucza, że całe stworzenie $\mathrm{w}$ formie doskonałej zaistniało w Logosie, w doskonałym prymordialnym człowieku. Natura ludzka była doskonała i w pełni wolna,

61 Eriugena, Periphyseon, Księga II, dz. cyt., 59.

62 Zob. Eriugenae Periphyseon, liber quintus, 912c-d. 
co doprowadziło do błędnego wyboru zwanego grzechem pierworodnym i sprowadziło człowieka do gorszej formy istnienia w rzeczywistości teofanicznej. Wraz z ludzką naturą, upadku doświadczyło całe stworzenie, które w człowieku pierwotnie powstało. Stwórca nie potępił jednak stworzenia i dopuścił możliwość powrotu do utraconego raju. Stworzenie zeszło z rzeczywistości prymordialnej do teofanicznej (określonej czasem i przestrzenią), więc w rzeczywistości prymordialnej (właściwej dla stworzenia) dokona się najpierw powrót powszechny, a następnie przebóstwienie wybranych. Pozaczasowy powrót do Boga posiada w systemie filozoficznym Eriugeny wymiar antropologiczny. Świadczy o tym: a) koncepcja powstania stworzenia w ludzkim intelekcie, b) wcielenie Logosu, c) sąd ostateczny - (samo) sąd, d) intencjonalny powrót do Boga. Wszystko, co najistotniejsze dla stworzenia, dotyczy natury ludzkiej, która dostąpi również przebóstwienia w tej części, w której w sposób właściwy współdziałała z łaską Boga. Przebóstwienie oznacza, że wybrane intelekty ludzkie zjednoczą się z absolutnie transcendentnym Bogiem, jednak nic nie narusza nigdy Bożej transcendencji, więc nigdy nie dojdzie do pomieszania natur Boga i ludzkiego intelektu. Wydaje się, że dla Eriugeny oczywiste jest, że fundamentalna różnica między Stwórcą i stworzeniem jest nieusuwalna w żadnej rzeczywistości. Istnienie Boga Stwórcy, ujęte przez Eriugenę jako istnienie niestworzonej natury stwarzającej, wyklucza możliwość utożsamienia stworzenia ze Stwórcą i zmieszania dwóch radykalnie odmiennych natur, co odnosi się również do Boga ujmowanego przez filozofa jako niestworzona natura stwarzająca. Natura stworzona nigdy nie stanie się naturą niestworzoną. Panteizm jest w systemie Eriugeny wykluczony, a wieczna szczęśliwość przebóstwionych będzie polegała na nieustannej kontemplacji, czyli nieustannym poznawaniu nieograniczonego i niepoznawalnego Boga.

Wydaje się, że Eriugena, rozważając problem przebóstwienia, wskazuje również na pewien fakt odnoszący się do jakości bycia człowieka jeszcze w teofanicznej rzeczywistości, i nie chodzi tylko 
o współdziałanie z łaską, dobre czyny i czyste sumienie, lecz o filozofię, którą Jan Szkot praktykował i polecał jako skuteczną metodę poznawania niepoznawalnego Boga. Ta filozoficzna praca, którą teraz wykonuje się w upadłym świecie, będzie wieczną szczęśliwością przebóstwionego intelektu i szczególną nagrodą dla podejmujących filozoficzny wysiłek poznawania Boga, jeszcze w okowach czasu, przestrzeni, materialnych ograniczeń i zmysłowych pragnień. Wydaje się, że w tym kontekście warto oddawać się tej pracy, ponieważ - według Eriugeny - droga do wiecznej szczęśliwości wiedzie przez szlak filozoficzny, łaskę Stwórcy i dobre życie, a nagrodą będzie przebóstwiony intelekt i kontemplacja Boga, który jest Prawdą.

\section{BIBLIOGRAFIA}

Bertin F., Les origines de l'homme chez Jean Scot, w: Jean Scot et l'histoire de la philosophie. Colloque du C.N.R.S., Laon jullet 1975, red. R. Roques, Bontemps Limoges, Paris 1977, 307-314.

Dietrich P., Duclow D., Paradise and Eschatology: Symbolism and Exegesis, w: „Periphyseon V'. Jean Scot-écrivain, red. G.-H. Allard, Éditions Bellarmin J. Vrin, Montréal - Paris 1986, 29-49.

Duclow D., Dietrich P., Hell and Damnation in Eriugena, w: History and Eschatology in John Scottus Eriugena and his time, red. J. McEvoy, M. Dunne, Leuven University Press, Leuven 2002, 247-366.

Duclow D., Dialectic and Christology in Eriugena's Periphyseon, Dionysius 4(1980), 99-118.

Eriugena Jan Szkot, Komentarz do Ewangelii Jana z Homiliq do Prologu Ewangelii Jana, tłum. z łac. A. Kijewska, ANTYK, Kęty 2000.

Eriugena Jan Szkot, Periphyseon, Księga I, przełożyła, wstępem i komentarzami opatrzyła A. Kijewska, Wydawnictwo Marek Derewiecki, Kęty 2009.

Eriugena Jan Szkot. Periphyseon, Księga II, przełożyła, wstępem i komentarzami opatrzyła A. Kijewska, Wydawnictwo Marek Derewiecki, Kęty 2010.

Eriugena Jan Szkot. Periphyseon Księga III, przełożyła, wstępem i komentarzami opatrzyła A. Kijewska, Wydawnictwo Marek Derewiecki, Kęty 2010.

Eriugena Jan Szkot. Periphyseon, Księga IV, przełożyła, wstępem i komentarzami opatrzyła A. Kijewska, Wydawnictwo Marek Derewiecki, Kęty 2012. 
Filipowicz A.M., Wieczność materii w kontekście polemiki Tertuliana z Hermogenesem, w: Ks. Józef Marceli Dotęga - pokorny uczony, cztowiek o wielkim sercu. Ksiega jubileuszowa, red. J. Sokołowski, Wydawnictwo UKSW, Warszawa 2010, 99-113.

Filipowicz A.M., Tertulian przeciwko Hermogenesowi, czyli spór o stworzenie świata, Wydawnictwo Naukowe UKSW, Warszawa 2018.

Gersh S., From Iamblichus to Eriugena. An Investigation of the Prehistory and Evolution of the Pseudo-Dionysian Tradition, Brill, Leiden 1978.

Gersh S., The Structure of Return in Eriugena's Periphyseon, w: Begriff und Metapher. Sprachform des Denkens bei Eriugena, red. W. von Beierwaltes, C. Winter, Heidelberg 1990, 108-125.

Głowa S., Bieda I., Breviarium Fidei. Wybór doktrynalnych wypowiedzi Kosciota, Księgarnia św. Wojciecha, Poznań 1997.

Iohannis Scotti Eriugenae Expositiones in Ierarchiam Coelestem, red. J. Barbet, Brepols, Turnhout 1975.

Iohannis Scotti seu Eriugenae Periphyseon, liber quintus, red. É. Jeauneau, (CChCM 165), Brepols, Turnhout 2003.

Jeauneau É., La Division des sexes chez Grégoire de Nysse et chez Jean Scot Erigène, w: Eriugena. Studien zu seinen Quellen, red. W. Beierwaltes, C. Winter, Universitätsverla, Heidelberg 1980, 341-364.

Kijewska A., Eriugena, Seria Myśli i ludzie, wyd. 1, Wydawnictwo Wiedza Powszechna, Warszawa 2005.

Kijewska A., Neoplatonizm Jana Szkota Eriugeny, Redakcja Wydawnictw Katolickiego Uniwersytetu Lubelskiego, Lublin 1994.

McGinn B., Eriugena Confronts the End, w: History and Eschatology in John Scottus Eriugena and His Time, red. J. McEvoy, M. Dunne, Leuven University Press, Leuven 2002, 183-202.

Moran D., The Philosophy of John Scottus Eriugena. A Study of Idealism in the Middle Ages, Cambridge University Press, Cambridge 1989.

Św. Augustyn, Niedokończony komentarz stowny do Księgi Rodzaju, w: Pisma egzegetyczne przeciw manichejczykom, tłum. z łac. J. Sulowski, ATK, Warszawa 1980, 83-112.

Św. Augustyn, Przeciwko manichejczykom. Komentarz stowny do Ksiegi Rodzaju, w: Pisma egzegetyczne przeciw manichejczykom, tłum. z łac. J. Sulowski, ATK, Warszawa 1980, 113-382.

Trouillard J., Érigène et la théophanie créatirice, w: The Mind of Eriugena. Papers of Colloquium, Dublin 1970, red. J. J. O’Meara, L. Bieler, Irish University Press, Dublin 1973, 98-113. 


\title{
THE CONCEPT OF DEIFICATION IN ERIUGENA'S PHILOSOPHICAL SYSTEM
}

\begin{abstract}
In the philosophical system of Eriugena, everything that exists is a nature that is composed of entities and non-beings. Entities are the part of nature that people can know. Non-beings are the part of nature which is unknowable by man. Being is the sensual part of human nature and material reality. For the human intellect, God, original causes and matter are non-beings. God created everything out of nothing in human nature. The unreasonable choice of man led to the fall of human nature and creation, which passed from perfection into existence in the material world. The Son of God became a man and brought about the salvation of humanity. In its last days, material reality will cease to exist and creation in human nature will come to a universal return to original perfection. Human intellects will make their own judgment and the chosen ones will turn to God. Then the deification of the elect will take place. There will be the unification of the creation with the Creator without confusion of natures, without removing fundamental ontological differences, and without pantheism, which in this concept is impossible. The divinities will contemplate God, which means that they will eternally know the unknowable. This happy vision of divinization, which is a continuous process of learning about God, may be attractive even for people interested in philosophical knowledge about God in the twenty-first century.
\end{abstract}

Keywords: Eriugena, God, Creator, creation, human nature, return, deification

\author{
Adam Grzegorzyca \\ grzegorzycaadam@gmail.com \\ Uniwersytet Opolski, Instytut Filozofii \\ Katowicka 89, 45-061 Opole
}

DOI: 10.21697/spch.2019.55.4.02 